\title{
FIRE SAFETY OF CNG BUSES - PROPER EXPERIENCES
}

\author{
Saša Milojevićl ${ }^{1}$ Radivoje Pešić, Dragan Taranović
}

UDC: $656.132+662.767$

DOI: $10.24874 / \mathrm{mvm} .2017 .43 .04 .03$

\begin{abstract}
Natural gas as engine fuel is a commercially very attractive option for medium and heavy duty vehicles. A combination of low gas price and incentives for environmentally friendly solutions are key arguments for bus fleet operators to convert to natural gas powered vehicles. From the second side, fuel can be dangerous if handled improperly. Gasoline and diesel are potentially dangerous fuels, but over time we are learned to use them safely. The same is true with liquefied petroleum gas and natural gas, as well as hydrogen. For commercial vehicles both, compressed natural gas and liquefied natural gas are equally relevant options. Recent fire accidents involving natural gas buses have shown that cylinders may explode through compliant with current UN ECE R110 regulation. Such a repeated scenario is certainly not acceptable having in mind the tremendous amount of energy released when a compressed cylinder burst. Recent accidents detailed in this paper highlights potential improvements in current natural gas buses fire safety concepts. Fire safety should not solely rely on cylinder behaviour when exposed to fire but also to additional and upstream fire safety barriers. Thermal fuses cannot be seen any more as an ultimate option to control cylinder burst in case of fire.
\end{abstract}

KEY WORDS: Fire safety, CNG buses, City transport

\section{POŽARNA BEZBEDNOST CNG AUTOBUSA - PRAVA ISKUSTVA}

REZIME: Prirodni gas kao pogonsko gorivo je komercijalno, vrlo atraktivna opcija za srednja i teška vozila. Kombinacija niske cene gasa i podsticaja za ekološki prihvatljivo rešenje su ključni argumenti za operatere voznih parkova da se vozila pogone na prirodni gas. Sa druge strane, gorivo može biti opasno ako se nepravilno rukuje. Benzin i dizel su potencijalno opasna goriva, ali vremenom smo naučili da ih bezbedno upotrebljavamo. Isto važi i za tečni naftni gas i prirodni gas, kao i za vodonik. Za komercijalna vozila, komprimovani prirodni gas i tečni prirodni gas su jednako relevantne opcije. Nedavne vatrogasne nezgode koje uključuju autobuse za prirodni gas pokazale su da cilindri mogu eksplodirati u skladu sa važećom regulativom UN ECE R110. Takav ponovljeni scenario sigurno nije prihvatljiv s obzirom na ogromnu količinu energije koja se oslobađa kada se komprimovani cilindar rasprsne. Nedavne nesreće opisane u ovom radu ističu potencijalna poboljšanja postojećih koncepta zaštite od požara u autobusima sa prirodni gasom. Protivpožarna sigurnost ne treba isključivo da se osloni na ponašanje cilindra kada je izložen vatri, već i na dodatne protivpožarne sigurnosne barijere. Termalni osigurači se više ne mogu gledati kao vrhunska opcija kontrole cilindara u slučaju požara.

KLJUČNE REČI: Protivpožarna bezbednost, CNG autobusi, Gradski prevoz

${ }^{1}$ Received October 2016, Accepted October 2016, Available on line first December 2017 
Intentionally blank 


\title{
FIRE SAFETY OF CNG BUSES - PROPER EXPERIENCES
}

\author{
Saša Milojević ${ }^{1}$, Radivoje Pešić ${ }^{2}$, Dragan Taranović ${ }^{3}$
}

\section{INTRODUCTION}

The transport sector has the second biggest greenhouse gas emissions in the EU. More than two thirds of transport-related greenhouse gas emissions are from road transport. Clean transport systems can fully meet the energy demand of the transport sector. Alternative low-carbon fuels should gradually substitute fossil fuels for transport propulsion in the long term. Clean and energy efficient vehicles have an important role to play in achieving EU policy objectives of reducing energy consumption, $\mathrm{CO} 2$ emissions, and pollutant emissions [1]. Natural gas as an automotive fuel offers important benefits to consumers, the environment and to the economy as a whole. It provides a quick and costeffective way to meet key objectives of the EU, including decarbonising road transport and improving air quality in cities. Natural gas as a vehicle fuel is available as compressed natural gas $(\mathrm{CNG})$ and liquefied natural gas (LNG) for cars, vans, buses and trucks, with many different models on the market today from established manufactures. LNG is furthermore becoming the fuel of choice for the shipping industry.

According to previous, natural gas as fuel for motor vehicles has more and more share and like the consequences to this fact are that today world has approximately 22.5 million of natural gas vehicles (NGVs); (in Europe 1.76 million). In the Republic of Serbia, in traffic exist more than 880 NGVs (90 heavy duty vehicles, where is about $60 \mathrm{CNG}$ powered buses and 800 cars and light duty vehicles) [2]. The number of CNG vehicle will be on the rise in Republic of Serbia, especially for public and private vehicles due to the introduction of $\mathrm{CNG}$ vehicles refuelling infrastructure.

CNG is stored on board vehicles under $20 \mathrm{MPa}$ in metallic or composite cylinders. Cylinders are manufactured under very strict safety norms and are subject to tests with pressures much higher than the ones existing during a regular refilling. Design and testing pressure is usually $30 \mathrm{MPa}$, they do not explode at less than $46 \mathrm{MPa}$, and the working pressure is $20 \mathrm{MPa}$. Because of reason of space, for buses, cylinders are associated in series (cylinders rack) and located on the roof $[3,4]$. By application of the CNG cylinders, that made by lightweight materials type III, and reconstruction of the supporting bus roof structure according to UN ECE Regulation No. 110, the aspects of vehicles safety in traffic was kept on high level. In addition, the rest of the CNG fuel line equipment must be also in accordance with UN ECE Regulation No. 110 and 115 [5,6].

Usually when it comes to CNG vehicle safety, all subjects in NGVs service have tended to focus their attention on the fuel cylinders. In reality CNG cylinder failures are

\footnotetext{
${ }^{1}$ Saša Milojević, M.Sc., Assistant R\&D, University of Kragujevac, Faculty of Engineering, Sestre Janjić 6, 34000 Kragujevac, Serbia, sasa.milojevic@kg.ac.rs

${ }^{2}$ Radivoje Pešić, Ph.D., prof., University of Kragujevac, Faculty of Engineering, Sestre Janjić 6, 34000 Kragujevac, Serbia, pesicr@kg.ac.rs

${ }^{3}$ Dragan Taranović, Assistant prof., University of Kragujevac, Faculty of Engineering, Sestre Janjić 6, 34000 Kragujevac, Serbia, , tara@kg.ac.rs
} 
relatively rare, certainly much less common than $\mathrm{CNG}$ vehicle fires. Potential causes of fire or ignition sources are also engine compartment and exhaust system, low voltage battery, heaters, wheel, garages, interior, etc. Mechanical (road accident) and thermal aggressions (on board or nearby fire) are the main causes that may lead to any of hazards. Whichever fuel is used, most vehicle fires have a non-fuel origin; unlike for other fuels, however, the consequences of a fire on the CNG fuel system can be very different due to the potential for high pressure jet flames to occur and in rare cases, cylinder failure and explosion.

Although CNG vehicle fires are no more common than fires on petrol and diesel vehicles, they do have their own special characteristics, so it is necessary to take them into account when implementing ways of preventing and controlling them. Therefore, we will concentrate in this article on CNG bus fire safety issues. After introducing the CNG bus fire safety topic, we will study some CNG bus fires will extract "lessons to be learned" for CNG and other compressed fuels (hydrogen as example).

\subsection{Natural Gas as Fuel for Motor Vehicles}

Natural gas is a naturally occurring fuel which requires very little processing before use. Chemically it normally consists of over $90 \%$ methane with smaller amounts of ethane, propane, butane, $\mathrm{CO}_{2}$, and other trace gases. The high methane content gives natural gas its high octane rating (120-130) and clean-burning characteristics, allowing high engine efficiency and low emissions [7].

From the other side, it is notable that natural gas in normal conditions has a low density of energy per unit volume. To meet all requirements needed to become engine fuel, it shall be a subject to appropriate treatment. The easiest way is to use CNG stored under high pressure into cylinders on the vehicle (working pressure of $20 \mathrm{MPa}$ ). Another possibility for increasing the energy density of natural gas in the fuel tank to the vehicle is its conversion into liquid form through the cooling up to $\left(-162{ }^{\circ} \mathrm{C}\right)$, and storing it into cryogenic cylinders like LNG $[7,8]$.

Before discussing the NGVs design, it is very important to understand some relevant properties of natural gas like vehicle fuel what makes this fuel different from gasoline or diesel. The items below summarize the basic differences between the properties of gaseous and liquid fuels that influence the NGVs design changes [7]:

- it is non-toxic, neither carcinogenic nor corrosive gas, but it is the stuffy

- natural gas is invisible but must been odorized so its presence can be detected

- $\quad$ unlike gasoline vapours, natural gas is lighter than air (methane has density of 0.68 $\mathrm{kg} \cdot \mathrm{m}^{-3}$ at $15^{\circ} \mathrm{C}$ ) and it is in the gaseous form at atmospheric conditions. In an event of a leak, this property allows to quickly rise and disperse in the atmosphere, while the propane $\left(1.87 \mathrm{~kg} \cdot \mathrm{m}^{-3}\right)$ and butane $\left(2.44 \mathrm{~kg} \cdot \mathrm{m}^{-3}\right)$ are heavy than air, and lower to floor

- Natural gas has an auto ignition temperature of around $\left(480\right.$ to $\left.650{ }^{\circ} \mathrm{C}\right)$ whereas gasoline is approximately $\left(260\right.$ to $\left.430{ }^{\circ} \mathrm{C}\right)$ and diesel less than $\left(260{ }^{\circ} \mathrm{C}\right)$. This relatively high auto ignition temperature for $\mathrm{CNG}$ is an additional safety feature of this fuel; and

- Methane has a very selective and narrow range of flammability. The mixture of gas in air by volume that will support combustion is between $(4.4$ and $15 \%)$. In other words, with less than $(4.4 \%)$, of the methane in air, the mixture will not burn because it is too lean, and with greater than (15\%), the mixture is too rich and will not burn. Ignitable range for gasoline is between $(1.4$ and $7.6 \%)$ and around $(0.6$ to $7.5 \%$ ) for diesel. 


\section{PROTOTYPE CNG BUS DESIGN PROPOSITION}

\subsection{Existing technical solutions for NGVs}

Substitution of existing fuels by natural gas in road transport can be realized by introducing of new vehicles equipped with original CNG engines, or as a first step, by converting engines of existing vehicles to CNG drive. To introduce natural gas as a fuel for road transport, the following options are possible [9]:

- modification of a gasoline engine to CNG combustion (so called conversion to a dedicated fuel)

- modification of a gasoline engine to either CNG or gasoline (two way/bi-fuel) combustion

- conversion of a diesel engine to dedicated CNG (spark ignition) combustion; and

- conversion of a diesel engine to dual fuel (gas and diesel combined) combustion.

For existing buses, driven by diesel engine, there are two options for conversion on CNG drive: conversion for dedicated or dual fuel combustion. The option can be selected, depending on the engine characteristics and the working conditions (routes, working time, available refuelling network etc.).

\subsection{Option of CNG storage and propulsion system demonstrated on city bus}

According to author's experiences, the best option for reconstruction of existing city buses is the using of completely new propulsion system with dedicated CNG combustion, Figure 1. In the bus, need to be integrated modern automatic fire protection system.

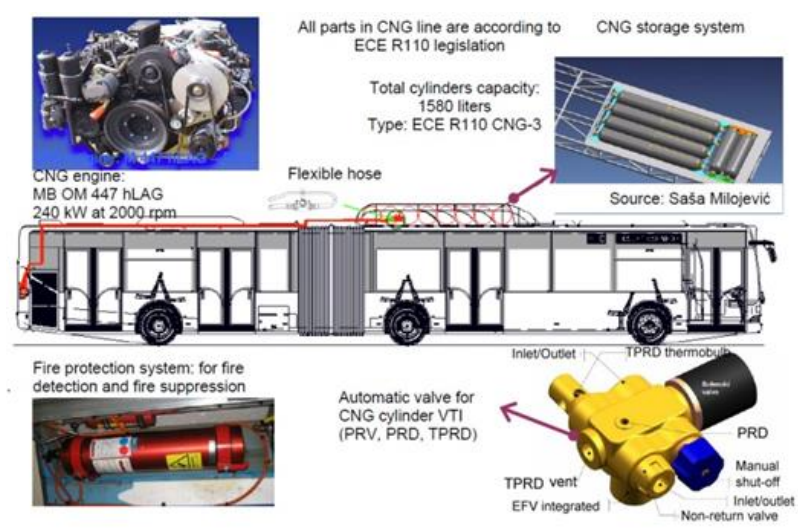

Figure 1. Proposed design of CNG fuel line equipment installed on the articulated bus $C N G-A S \circledR$

On the Figure 1 are shown parts of the installation for CNG supply from bus roof mounted gas cylinders to the engine that is proposed to prototype version of articulated bus CNG-AS®. 
The retrofit of diesel bus into dedicated NGV was realized with the joining of the CNG cylinders with the original rack, to the bus roof. It was selected CNG storage system that includes type III cylinders composed of an aluminium 6061 liner reinforced by carbon fiber in epoxy resin $\left(\right.$ Dyne-cell ${ }^{\circledR}$ ), with a favorable ratio between weight and volume $\left(0.3-0.4 \mathrm{~kg} \cdot \mathrm{L}^{-1}\right)[3,4,10]$.

\section{FURTHER IMPROVING THE FIRE SAFETY OF CNG BUSES}

Although CNG vehicle fires are no more common than fires on petrol and diesel vehicles, they do have their own special characteristics, so it is necessary to take them into account when implementing ways of preventing and controlling them.

Vehicle fires can have a number of causes, the vast majority of which are nonfuel related. For example, fire can be caused by electrical faults, or start in the engine compartment due to the failure or leakage of operating fluid hoses causing the spilling of lubricants, hydraulic fluids or even coolant on hot engine surfaces. Vehicle fires can also originate in seized brakes and overheated tires. Vehicles have been set on fire by occupant smoking, or even as a result of arson. Engine compartment fire is the most frequent type of vehicle fire $(71 \%)$, Figure 2 [11].

Fire on some CNG vehicles has been caused by gas leaked from damaged CNG components (e.g. pipe connections), which is then ignited by the numerous live ignition sources on an operating vehicle. Such fires can be started in traffic collisions when the CNG components are damaged resulting in gas release.

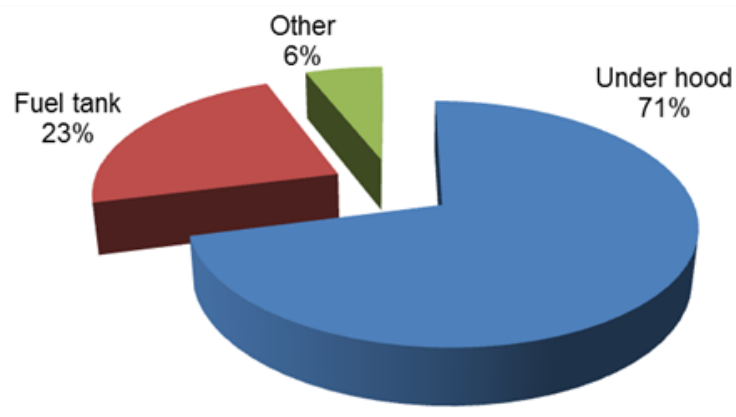

Figure 2. Causes of vehicle fire

\subsection{Consequences of a CNG vehicle fire}

On a CNG vehicle, a fire not involving the gas system has similar characteristics and outcomes as vehicles using the conventional fuels. However, if the gas system develops a leak or releases gas, or the CNG cylinder pressure relief devices (PRDs) are activated, a gas fire will be added to the general fire. If the gas is released at high pressure, e.g. through the PRDs, it can be in the form of a large, powerful jet flame which can reach several meters beyond the vehicle perimeter, Figure 3 [3]. 


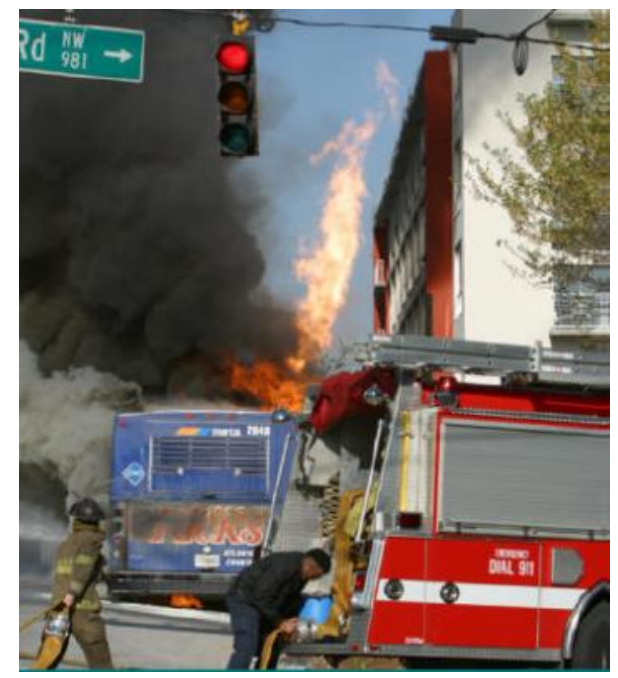

Figure 3. Long and intense jet flame in a CNG bus fire (Jet flame direction is good, but still perilously close to inhabited building)

Jet flame may take place suddenly and present an unexpected hazard which could be very injurious to persons involved who are not prepared for this event. Vehicle drivers and the emergency service personnel should be aware of this possibility and take appropriate precautions to avoid injury or damage to both themselves and bystanders or other vehicles.

If the fire finally reaches the on-board fuel storage area but fortunately very rarely, the PRDs fail to deploy, a cylinder failure might result, in some cases as soon as within a few minutes of the fire starting, with explosive pressure and shrapnel reaching people and vehicles several meters away. In most explosions the vehicle is completely destroyed, but it is the projectiles that cause the most damage and casualties, at a longer distance, rather than the pressure wave itself.

The most unwanted event in case of CNG bus fire is the burst of one or more of the compressed storage cylinders located on the roof of the vehicle. Cylinder burst is definitely not a tolerable option having in mind the tremendous amount of mechanical and chemical energy released in the course of this event.

The current safety strategy to prevent tank burst consists in fitting pressurized cylinders with devices that release stored compressed natural gas as they fuse under the effect of temperature rise (fire). The melting temperature of these fuses is about $\left(110 \pm 1^{\circ} \mathrm{C}\right)$. This is so called temperature pressure relief devices (TPRDs), which are integrated inside automatic cylinder valve, Figure 1. In practical terms, to prevent cylinder burst, internal cylinder pressure has to decay before the fire degrades the mechanical strength of the CNG cylinder. Experience shows that unprotected cylinder (inhibited PRDs) cannot survive a standard bonfire test for more than few minutes. The main cause for a tank to burst is the decay of its mechanical strength and rise in internal pressure [5,12]. According to experience, bus cylinder can be exposed to fire for about $(20 \square 30) \mathrm{min}$, which is an average time frame for a bus to be burnt out. Therefore, PRD should be capable of depressurizing cylinder within a couple of minutes, when CNG fuel cylinders were prevented from failing, Figure 4 [13]. 

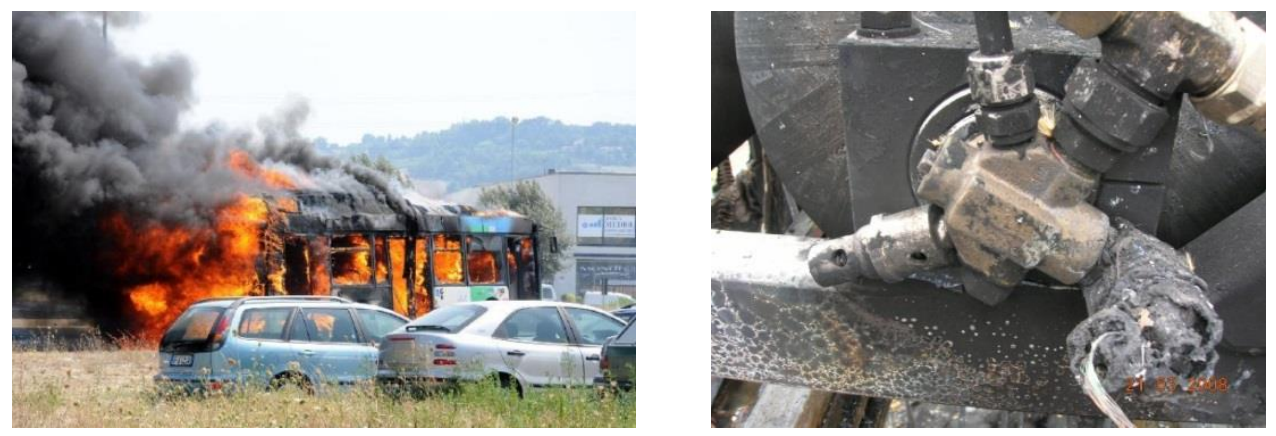

Figure 4. CNG bus under fire (left) and PRD which were successfully activated in a fire (right)

Any compressed cylinder or cylinder rack must be certified and submitted to standardized bonfire test according to UN ECE Regulation No. 110 [5]. As example, proposed cylinders (Dyne-cell $\left.{ }^{\circledR}\right)$ was demonstrated superior performance results in the fire test compared to other lightweight cylinders. Cylinders were exposed to extreme temperatures from fire for up to 20 min without rupturing, Figure 5 [13].

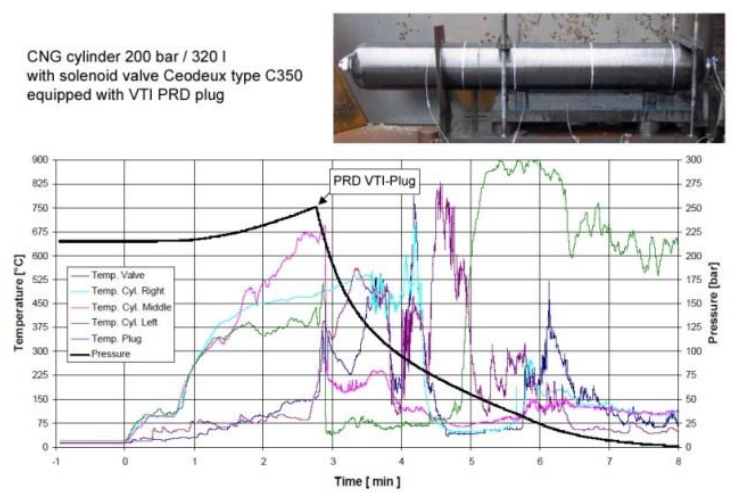

Figure 5. Bonfire test results of CNG cylinder type (Dyne-cell ${ }^{\circledR}$ )

Related to previous, though cylinder burst is not supposed to be happen, recent CNG buses cylinder bursts have highlighted potential deficiencies in the existing fire safety concept [12].

\subsection{CNG cylinder burst}

Large quantity of mechanical and chemical energy is stored in compressed combustible gas storage. Sudden release of this energy in case of cylinder burst may cause some severe damage to the bus environment

When a cylinder bursts, observation shows two consecutive pressure waves propagating in the surrounding environment. The first one which is also the more severe is associated with the pneumatic rupture (gas expansion) whereas the second is caused by the combustion of the released combustible gas into the air (fire ball). It is therefore to be noticed that although the chemical energy stored is usually an order of magnitude larger than the mechanical energy, the sudden release of the mechanical energy induces greater overpressure effects. 
Theoretically, the pneumatic burst of a 130 liter cylinder at a pressure of $20 \mathrm{MPa}$ releases an energy equivalent to the detonation of about $1.85 \mathrm{~kg}$ of TNT (8.7 MJ). Windows can be broken within a 30 meters radius and pressure wave induced lethality is to be foreseen within a radius of 12 meters. These calculations can worsen due to pressure wave reflection and pressure build up as well as to directional energy release (axial direction) due to the rupture mode of the cylindrical tank. Moreover, projectiles can also cause severe damages within a radius much larger than the one estimated above for overpressure effects. Researches shows that fragments of up to $14 \mathrm{~kg}$ (type IV tank filled with hydrogen at 35 $\mathrm{MPa}$, test conducted in open atmosphere, projectiles not hindered by bus equipment) have travelled a distance of $82 \mathrm{~m}$ cylinder fire location. The mechanical energy released as the cylinder ruptured was equivalent to about $1.35 \mathrm{~kg}$ of TNT (6.3 MJ) [12]. Therefore, an unacceptable event such as the cylinder burst induces a significant damage radius (missiles and overpressure) that goes far beyond the bus geometry.

This makes a major difference with conventional liquid fuel buses with damage radius in case of fire limited to the bus itself (unless the fire propagates).

\subsection{CNG vehicle fire protection provisions and firefighting techniques}

Fire safety requires a comprehensive approach including CNG vehicle and gas component design, layout and installation, good maintenance, and appropriate firefighting techniques.

On CNG cylinders PRDs are fitted to enable their contents to be safely vented in the event of fire, thus preventing destructive cylinder failure, see Figure 6. To respond safely in a fire, CNG cylinders must be fitted with PRDs which are recommended by the cylinder manufacturer, and which have been used successfully in the design qualification testing of the cylinder (the standard bonfire test).
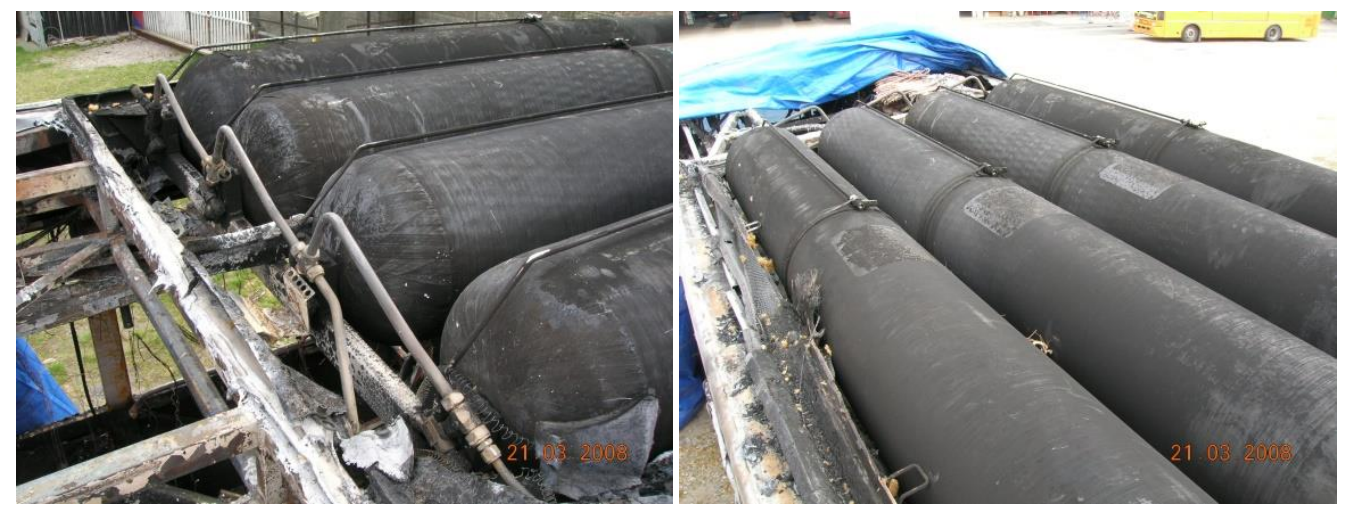

Figure 6. These CNG cylinders were prevented from failing by PRDs which were successfully activated in a fire

CNG cylinders must be installed in such a way that their PRDs are not thermally shielded in feasible fire scenarios. The PRD ports should be so directed their jet flames will not hit other vehicles and persons on the street when activated. CNG vehicle installation/conversion and CNG vehicle design should take these into account.

Many CNG buses are equipped with portable fire extinguishers. However, their size in many cases may not put out even a small vehicle fire, if they are not, or cannot, be directed at the appropriate place or their contents run out before the fire can be put out. 
Consideration should be given to adequate extinguisher sizing and the drivers should be trained to use them correctly.

On many CNG buses the drivers can, from their seat, operate an isolation shut off valve on the CNG fuel storage system. This action should be emphasized, as it would minimize any jet flames resulting from the release of gas from damaged downstream components. In recent years, as a result of CNG bus fires, some CNG buses have been equipped with fire warning and automatic engine fire suppression systems. There are other simple, less costly engine firefighting methods which less well-resourced bus operators might need to resort to if automatic suppression is unaffordable. Even with automatic suppression in use, however, good firefighting techniques and procedures should still be in place for fires on the CNG system outside the engine compartment, or brakes and tires. The automatic engine fire suppression system must not be seen as obviating the need for other fire safety measures, e.g. the fire safety features of the on-board CNG cylinder installation.

As the majority of $\mathrm{CNG}$ vehicle fires have non-gas origins, regular CNG vehicle maintenance should be no less than that normal maintenance of vehicles using other fuels, in addition recognizing system defects with fire potential. For example, close attention to the condition of brakes, tires, turbochargers, operating fluid piping and the general tidiness and cleanliness of the engine could play an active role in preventing a large proportion of vehicle fires.

The serious potential consequences of a CNG vehicle fire that has spread to the onboard gas storage system mean that it is vital that, while it is still safe to do so, efforts should be made to put out an initially small vehicle fire. However, a CNG vehicle fire may take only a few minutes to complete vehicle destruction, and the emergency response agencies will likely arrive on the scene well past the initial, manageable stage, Figure 4 (left). As the first respondent is likely to be the vehicle operator, the task of fighting this initial fire will therefore likely falls on the driver. For this reason, drivers should be adequately equipped and given good CNG vehicle fire knowledge and effective training for fighting the initial fire.

\subsection{Fire protection system of CNG buses}

Fire protection system includes a fire detection system which may or may not include a fire suppression system. The purpose is to define the minimum performance requirements for detection of and suppression of thermal events on transit vehicles. The fire protection system shall be capable of detecting and minimizing potential damage of fire events in critical zones of the vehicle identified in this document.

Fire on board buses may be caused by internal or external factors. As explained above, experience shows that fires usually start in the engine compartment, Figure 2. As far as external causes are concerned we can mention human error during maintenance (use of open flame), vandalism and propagating fires from nearby vehicles or infrastructure. Generally, most fires start in engine compartment. A well-developed fire in engine compartment often has a very intensive course of event and is impossible to fight with a hand extinguisher. The solution is a permanently installed and fully automatic fire suppression system.

Related to the previous, $\mathrm{CNG}-\mathrm{AS} \circledast$ bus is equipped with a fully automatic fire suppression system for the engine compartment and possible separate heating areas, Figure 7. This system is also applicable for Hydrogen powered buses [14]. Scheme of installation the component system for detecting and fire extinguishing on the bus is shown in Figure 8 [15]. 

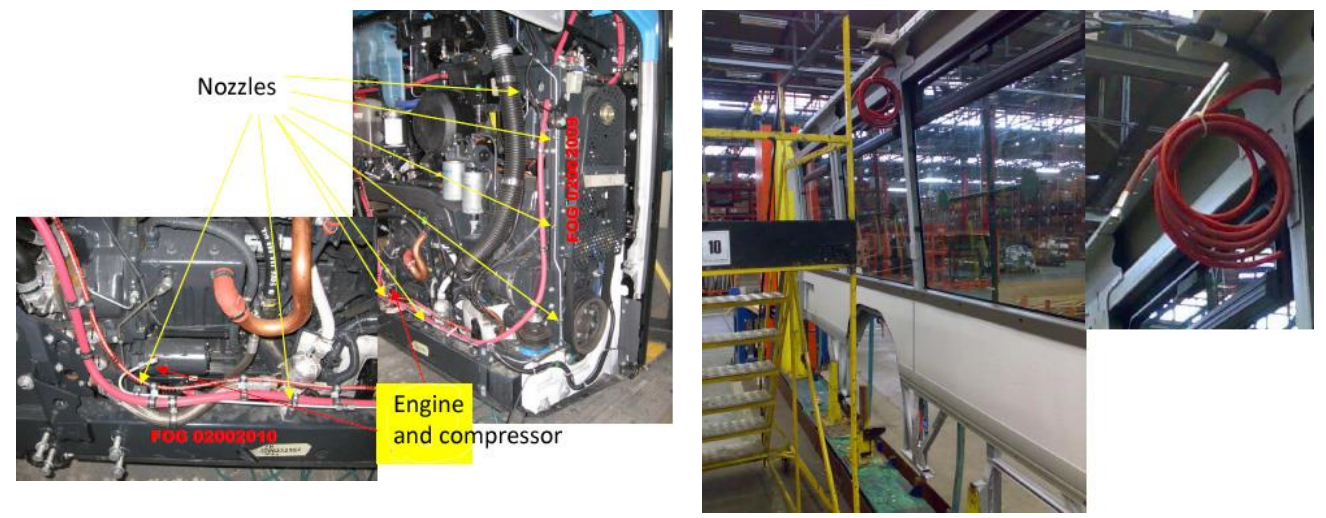

Figure 7. Nozzles of the fire-extinguishing system, positioned in the engine compartment

The system is activated hydro-pneumatically and works without any power supply, Figure 8. When releasing, the suppressant is sprayed through nozzles that break down the fluid into pillar-shaped mist clouds that cool the temperature and force the air out. The suppressant is mainly based on anti-freeze water. The releasing time is normally between

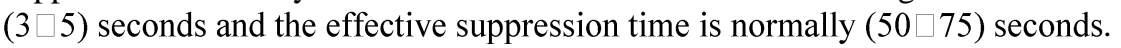
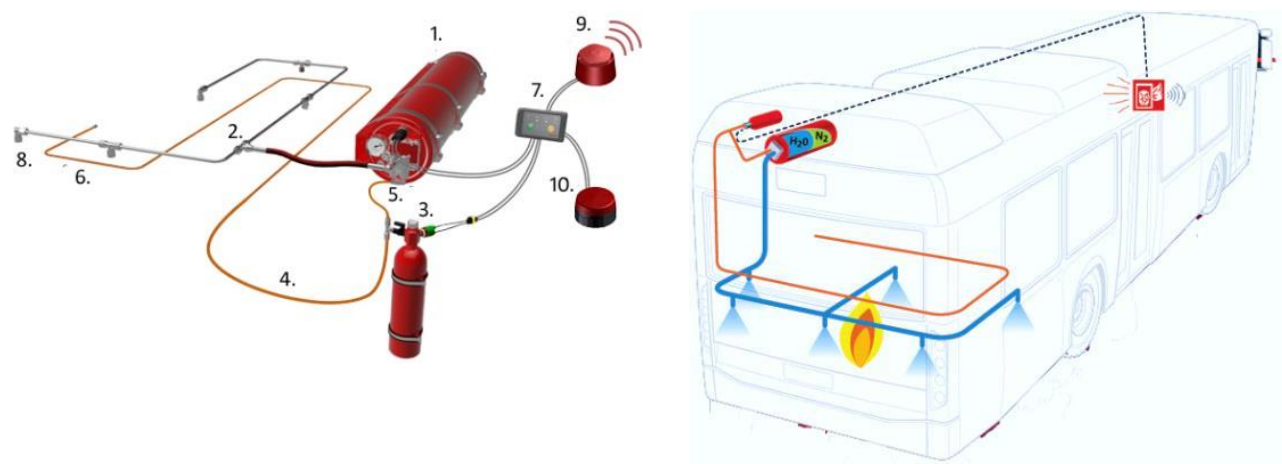

Figure 8. Overview of fire suppression system components

The piston accumulator with extinguishing fluid, pressurized to (10-10.5) $\mathrm{MPa}$ (1) is connected to a distribution system with a distribution hose and pipe as well as patented nozzles (2). The detector bottle (3) pressurized to between (2.4 and 3.1) MPa (depending on model) is connected to a detection system made of polymer tube (4). The piston accumulator and detector bottle is inter-linked via a patented valve (5) that keeps the piston accumulator closed when the pressure in the detector bottle is normal, Figure 8.

If there is a fire the detection tube bursts (6), the pressure falls in the detection system and the valve in the piston accumulator opens. The pressure switch warns the driver via the alarm panel (7) sounds (9) and light signals (10). The extinguishing fluid is pressed through the distribution system's nozzles and a water mist is spread in the protected compartment (8).

High pressure water is a far superior fire suppression technique in engine compartments. The high pressure in combination with special nozzles creates micro droplets with an average size of $50 \mu \mathrm{m}$. As a comparison, 8000 of these micro droplets are needed to 
fill a regular water drop of $1 \mathrm{~mm}$ in diameter, Figure 9 (left). In case of fire, one liter of extinguishing fluid absorbs 540,000 kilocalories and produces 1,700 liters of water mist at the same time, Figure 9 (right).
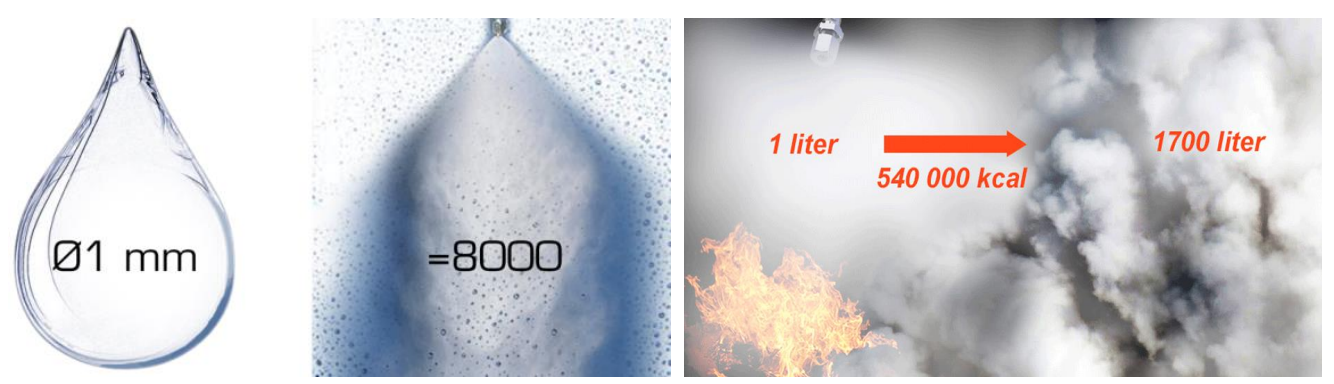

Figure 9. Normal sized water drop vs. water mist and extinguishing fluid water mist effects

During fire suppression, all components in the fire triangle chain reaction must be combated, Figure 10 (left). First, heat: In the evaporation process the water mist cools the burnt gases and hot parts in the engine compartment. One calorie is needed to warm one gram of water $\left(+1^{\circ} \mathrm{C}\right)$, but 540 times more to evaporate the same quantity of water from $(+0$ $\left.{ }^{\circ} \mathrm{C}\right)$ to vapor. The effective cooling contributes to a rapid extinguishing and reduces the risk of re-ignition. Second, Oxygen: The micro droplets evaporate immediately upon contact with heat. In the evaporation, 1 liter of water forms 1700 liters of water vapor, Figure 9 (right). The vapor increases the water content of the air and prevents a new supply of Oxygen to the fire. Third, fuel: The extinguish-ant also includes a low concentration of aqueous film forming foam coating the fuel, preventing its contact with Oxygen, resulting in suppression of the combustion.
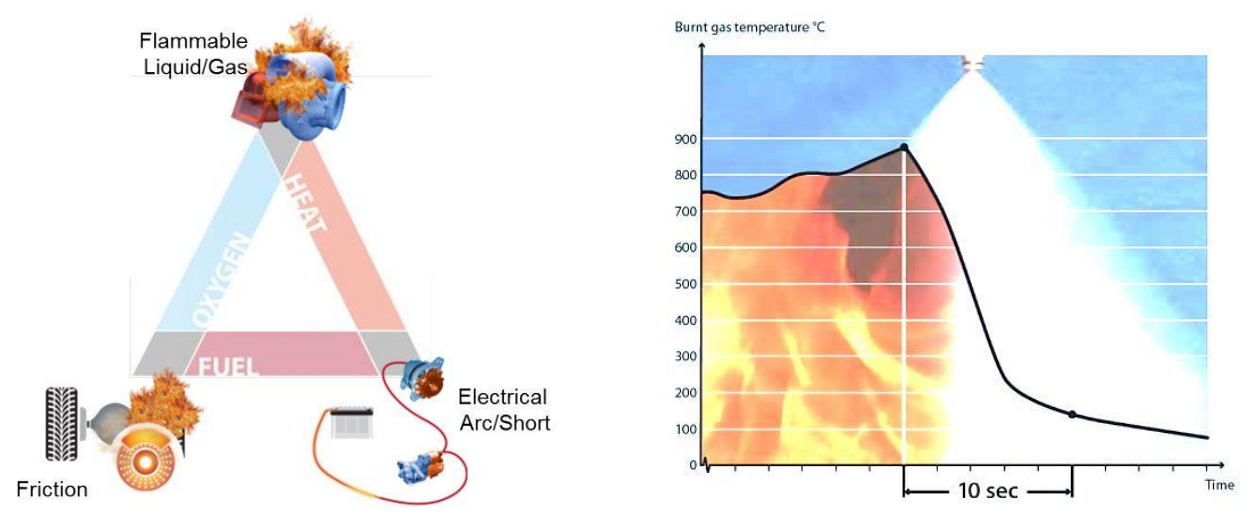

Figure 10. Fire triangle and fire suppression test results

According to fire suppression test in a simulated engine compartment, the fire develops during $20 \mathrm{~s}$. The burnt gas temperature increases first to $\left(870{ }^{\circ} \mathrm{C}\right)$, after that fire suppression system is activated manually. In next $10 \mathrm{~s}$ the burnt gas temperature decreases to approximately $\left(136^{\circ} \mathrm{C}\right)$ which is normal temperature, Figure 10 (right) [15]. In addition 
to the rapid extinguishing the risk of reigniting and melting damage to plastics, rubber and cables is minimized. This means reduced repairs and down time of vehicles.

\section{CAUSES OF FIRE WITHIN CNG BUSES - RECOMMENDED PRACTICE}

According to recommended practice, the potential causes of fire or ignition sources are usually divided into 10 critical zones within the bus, Table 1 . This recommended practice provides guidelines for CNG bus fire suppression systems in conjunction with a vehicle fire. For fire detection system there are two basic sensor devices that are used to provide early warning of fires. Thermal sensors detect heat and optical sensors detect flame. For engine compartment need to be installed mix of thermal sensors and optical infrared sensor (usually minimum 4 thermal sensors is used). A control panel should be provided for all detection and/or suppression systems. The control panel should provide, at a minimum, electrical supervision of system power and detection; and system actuation wiring circuits if so equipped. The control panel should be visible an At a minimum the system control panel should include an alarm and signal system. Both a fire and a fault should activate a visual and audible alarm.

All lines, wiring, hoses, cables, and lines must be properly bracketed, insulated, and isolated to avoid chaffing and to protect against heat sources, using heat shields. Power for the fire protection system shall be provided by the bus electrical system directly from the vehicle battery terminals or through dedicated power and ground buss barsd accessible to the seated driver/operator.

Table 1. Potential causes of fire or ignition sources - zones

\begin{tabular}{|c|c|c|}
\hline Zones & $\begin{array}{c}\text { Location within the } \\
\text { bus }\end{array}$ & Ignition sources \\
\hline Zone 1 & Engine compartment & $\begin{array}{c}\text { electrical, combustible or flammable } \\
\text { liquids/solids/gases, hot surfaces, belts, clutches, turbo } \\
\text { fire, ignition of exhaust blankets, catalytic converter }\end{array}$ \\
\hline Zone 2 & $\begin{array}{c}\text { Exhaust system } \\
\text { (external to engine } \\
\text { compartment) }\end{array}$ & $\begin{array}{c}\text { high temperatures, exhaust leak, tail pipe fire, ignition } \\
\text { of exhaust blankets, catalytic converter and monitoring } \\
\text { systems }\end{array}$ \\
\hline Zone 3 4 & $\begin{array}{c}\text { Low voltage battery } \\
\text { electrical, flammable liquids/solids/gases, cables, } \\
\text { equalizers, circuit breakers, fusible link malfunction, } \\
\text { corrosion, overcharge, battery box }\end{array}$ \\
\hline Zone 5 & $\begin{array}{c}\text { Heating ventilation air } \\
\text { conditioning system - } \\
\text { HVAC }\end{array}$ & $\begin{array}{c}\text { under inflated tire, overheated bearings, leaky wheel } \\
\text { seal, flammable liquids/solids, high heat in brake area, } \\
\text { road debris }\end{array}$ \\
\hline Zone 6 & $\begin{array}{c}\text { Operator's work } \\
\text { station }\end{array}$ & $\begin{array}{c}\text { electrical, flammable liquids/solids/gases, high heat, } \\
\text { tobacco smoking, debris build up }\end{array}$ \\
\hline
\end{tabular}




\begin{tabular}{|c|c|c|}
\hline Zone 7 & Articulated turn table & $\begin{array}{l}\text { friction, debris build up, electrical cabling, vandalism, } \\
\text { tobacco smoking }\end{array}$ \\
\hline Zone 8 & $\begin{array}{l}\text { Fuel storage (inclusive } \\
\text { of roof mounted } \\
\text { cylinders) }\end{array}$ & $\begin{array}{c}\text { Fuel leaks, arcing, debris, flammable } \\
\text { liquids/solids/gases, cables, equalizers, circuit breakers, } \\
\text { fusible link malfunction, corrosion, overcharge }\end{array}$ \\
\hline Zone 9 & $\begin{array}{l}\text { Electrical junction } \\
\text { boxes }\end{array}$ & $\begin{array}{l}\text { shorts, electrical, flammable liquids/solids, cables, } \\
\text { equalizers, circuit breakers, fusible link malfunction, } \\
\text { corrosion, chaffing }\end{array}$ \\
\hline $\begin{array}{c}\text { Zone } \\
10\end{array}$ & Interior & $\begin{array}{l}\text { tobacco smoking, debris, HVAC duct, fluorescent light } \\
\text { ballast, corrosion, cabling, chaffing, signage, wire } \\
\text { harnesses, vandalism, advertisements }\end{array}$ \\
\hline
\end{tabular}

\section{CONCLUSIONS}

(1) The numbers of fires in buses and coaches is up to 5-10 times higher than the number of fires in vans and Lorries. Fire onboard buses may be caused by internal or external factors. Most of these fires occur in the vehicle's engine compartment which is often located at the rear of the bus or coach. This makes it difficult for the driver to discover a fire.

(2) Most unwanted event in case of CNG bus fire is the burst of one or more of the compressed storage cylinders located on the roof of the vehicle. Cylinder burst is definitely not a tolerable option having in mind the tremendous amount of mechanical and chemical energy released in the course of this event.

(3) CNG cylinders must be equipped with PRD that should be capable of depressurizing cylinder within a couple of minutes, when CNG fuel cylinders were prevented from failing. Any compressed cylinder or cylinder rack must be certified and submitted to standardized bonfire test according to UN ECE Regulation No. 110.

(4) Fire protection system includes a fire detection system which may or may not include a fire suppression system. The fire suppression system applies primarily to fire protection of passengers and personnel. Another important aspect is the protection of property where the effectiveness of the system means that damage to machines and material will be small and result in low repair costs.

(5) Research has shown that extinguishing with water mist is 2-3 times more effective than traditional methods. High pressure water is a far superior fire suppression technique in engine compartments.

(6) According to recommended practice, the potential causes of fire or ignition sources are usually classified into 10 critical zones. The recommended practice provides guidelines for CNG bus fire suppression systems in conjunction with a vehicle fire.

\section{ACKNOWLEDGMENTS}

The paper is a result of the research within the project TR 35041 financed by the Ministry of Science and Technological Development of the Republic of Serbia. 


\section{REFERENCES}

[1] European Commission, Climate action: Reducing emissions from transport, 2016. http://ec.europa.eu/clima/policies/transport/ (accessed 15.05.2016).

[2] Gas Vehicle Report, Worldwide NGV Statistics, Int. J. of NGV group, 15\#1, 168, 2023, 2016.

[3] Rasche, C. (2009). Advanced Lightweight Fuel Storage Systems TM, Dynetek Europe GmbH Presentation, Ratingen, Germany.

[4] Milojevic, S. and Pesic, R., Theoretical and experimental analysis of a CNG cylinder rack connection to a bus roof. Int. J. Automotive Technology, 13, 3, 497-503, 2012.

[5] UN ECE Regulation No. 110 Rev.3 $\square$ CNG and LNG vehicles, http://www.unece.org/trans/main/wp29/wp29regs101-120.html. (accessed 15.05.2016).

[6] UN ECE Regulation No. 115 Rev.1 - LPG and CNG retrofit systems, http://www.unece.org/trans/main/wp29/wp29regs101-120.html, (accessed 15.05.2016). .

[7] Pešić, R., Petković, S. and Veinović, S., Motor Vehicles and Motors - Equipment, Faculty of Mechanical Engineering in Kragujevac and Banja Luka, University Book of 536 pages, 2008.

[8] Milojevic, S. and Pesic, R.:, CNG buses for clean and economical city transport. Int. J. Vehicle Mech., Engines and Transportation Syst., 37, 4, 57-71, 2010.

[9] Milojević, S. and Pešić, R., Logistics of natural gas applications as engine fuel. JUMTO Journal Tractors and Power Machines, 16, 2, 68-74, 2011.

[10] Stojanovic, B., Glisovic, J. Automotive Engine Materials, in: Saleem Hashmi (Ed), Reference Module in Materials Science and Materials Engineering, Oxford: Elsevier, pp. 1-9, 2016.

[11] Bahouth, G., Post-Crash Exterior Crush Patterns and Motor Vehicle Fire Occurrence. SAE Paper 2006-01-0789, 2006.

[12] Perette, L., Wiedemann, H. K., CNG buses fire safety: Learnings from recent accidents in France and Germany. The open archive HAL, 2014.

[13] Rasche, C., Modern Composite Flaschen und die Anforderungen fur deren sicheren Betrieb aus Sicht der Speicherhersteller, Dynetek Europe GmbH Presentation, Ratingen, Germany, 2003.

[14] Milojević, S., Reconstruction of existing city buses on diesel fuel for drive on Hydrogen. Journal of Applied Engineering Letters, 1, 1, 16-23, 2016.

[15] Fogmaker: Effective fire suppression with high pressure water mist for engine compartments, http://fogmaker.com/wpcontent/uploads/2016/02/Bussfolder_ENG_8050-01-002.pdf, (accessed 15.05.2016). 